Article

\title{
Towards Risk-Sensitive and Transformative Urban Development in Sub Saharan Africa
}

\author{
Hayley Leck ${ }^{1, *}$, Mark Pelling ${ }^{1}$, Ibidun Adelekan ${ }^{2}$, David Dodman ${ }^{3}$, Hamadou Issaka ${ }^{4}$, \\ Cassidy Johnson ${ }^{5}$, Mtafu Manda ${ }^{6}$, Blessing Mberu ${ }^{7}$, Ezebunwa Nwokocha ${ }^{8}$, \\ Emmanuel Osuteye ${ }^{5}$ and Soumana Boubacar ${ }^{9}$
}

1 Department of Geography, School of Global Affairs, King's College London, London WC2R 2LS, UK; mark.pelling@kcl.ac.uk

2 Department of Geography, University of Ibadan, Ibadan 200284, Oyo State, Nigeria; ibiadelekan@yahoo.com (I.A.); miczeze@yahoo.com (E.N.)

3 Human Settlements Research Group, International Institute for Environment and Development, 80-86 Grays Inn Rd, London WC1X 8NH, UK; david.dodman@iied.org

4 Département de Géographie et Aménagement de l'Espace, Institut de Recherches en Sciences Humaines, Université Abdou Moumouni de Niamey, BP 10896, Niamey, Niger; hamadouissaka@yahoo.fr

5 Bartlett Development Planning Unit, University College London, 34 Tavistock Square, Bloomsbury, London WC1H 9EZ, UK; cassidy.johnson@ucl.ac.uk (C.J.); e.osuteye@ucl.ac.uk (E.O.)

6 Urban and Regional Department, Mzuzu University, Private Bag 2, Luwinga, Mzuzu, Malawi; mtafu.manda@gmail.com

7 African Population and Health Research Centre, APHRC Campus, Manga Cl, P.O. Box 10787-00100 Nairobi, Kenya; bmberu@aphrc.org

8 Department of Sociology, University of Ibadan, Ibadan 200284, Oyo State, Nigeria; miczeze@yahoo.com

9 Agroéconomiste, Département de Sociologie et Economie Rurales, Faculté d'Agronomie, Université Abdou Moumouni, BP 10960, Niamey, Niger; san_boub@yahoo.fr

* Correspondence: hayley.leck@kcl.ac.uk; Tel.: +44-20-7848-1054

Received: 26 May 2018; Accepted: 20 July 2018; Published: 27 July 2018

check for updates

\begin{abstract}
Risk-sensitive urban development is required to reduce accumulated risk and to better consider risk when planning new developments. To deliver a sustainable city for all requires a more frank and comprehensive focus on procedure: On who makes decisions, under which frameworks, based upon what kind of data or knowledge, and with what degree and direction of accountability? Acting on these procedural questions is the promise of transformative urban development. This paper explores the status of risk sensitive and transformative urban development and the scope for transition towards these components of sustainability in urban sub-Saharan Africa through the lens of diverse city cases: Karonga (Malawi), Ibadan (Nigeria), Niamey (Niger) and Nairobi (Kenya). The paper draws from a 3-year research and capacity building programme called Urban Africa: Risk Knowledge that aims to address gaps in data, understandings and capacity to break cycles of risk accumulation. A common analytical framework is presented to help identify blockages and opportunities for transition towards a risk-sensitive and transformative urban development. This framework is then illustrated through each city in turn and a concluding discussion reflects on city observations to draw out recommendations for city level and wider action and research partnerships.
\end{abstract}

Keywords: risk-sensitive development; transition; transformative urban development; sub-Saharan Africa

\section{Introduction}

The Sustainable Development Goals (SDGs) challenge urban planners, risk professionals, researchers and citizens to extend their focus of activity from accounting for the status of risk towards 
understanding and acting on the processes that can enable a transition towards more risk-sensitive and transformative urban development across all contexts. Risk-sensitive development is required to reduce risk that has accumulated in the city and to better consider risk when planning new developments, often under conditions of uncertainty and threats [1]. This includes more appropriate building design, construction and land-use planning, enhanced infrastructure access and maintenance, risk awareness raising, and planning for emergency response and reconstruction including social safety nets and insurance. Though long present in most urban or national authority city development or risk management plans, urban losses continue to grow. To deliver a sustainable city for all requires a more frank and comprehensive focus on procedure: On who makes decisions, under which frameworks, based upon what kind of data or knowledge, and with what degree and direction of accountability? Integrative and inclusive governance across all scales is an essential underpinning. Acting on these procedural questions is the promise of transformative urban development. This paper explores the status of risk-sensitive and transformative urban development and the scope for transition towards these components of sustainability in urban sub-Saharan Africa (sSA) through the lens of diverse city cases.

sSA is important because of large proportions of urban populations with high vulnerability and growing exposure to risks [2]. High rates of urban growth pose increasing risks moving into the future yet there is also opportunity to reduce risk through integrating risk management into development and for reforming urban development processes [3]. However, this opportunity space is often constrained by limited capacities to plan and manage rapid urban growth in many African towns and cities, particularly in bourgeoning informal settlements. Limited capacities to prevent processes of risk accumulation pose threats to poverty reduction and sustainable development [4]. In this context, there is an increasingly urgent need for squarely recognising and addressing the underlying vulnerabilities of urban populations and their root causes. Transitioning towards such sustainable urban pathways will require the strengthening of capacities and accountability of city authorities and broader governance systems, both formal and informal [5]. Complex relationships between risk (likelihood of future loss and damage) and vulnerability (propensity or predisposition to be adversely affected) and other elements of development and human well-being require detailed analysis and advanced understandings [6]. This connects to SDG's which integrate risk management throughout, specifically in Goal 1: Eradicating Poverty, and Goal 11: Sustainable Cities and Communities. Particularly important for the SDGs is understanding and addressing the full spectrum of risk, encompassing everyday risks (e.g., environmental/public health risk; man-made hazards-poor solid waste management), small and large events, their interlinkages and relative changes in their nature, scale and distribution [2].

This paper draws from a large multi-disciplinary, multi-country programme of research and capacity building-Urban Africa: Risk, Knowledge (Urban ARK) focused on understanding risk in sSA. The programme works in nine cities across eight countries and aims to address gaps in data, understandings and the capacity to break cycles of risk accumulation. This is pursued through a partnership between researchers, practitioners and city and community level activists. Experience and analysis of four cities in particular are considered in this paper: Karonga, a small town in northern Malawi; Ibadan, a regional centre in Nigeria; Niamey, capital city of Niger and Nairobi, capital city of Kenya and a regional core city. These four cities are chosen for their regional coverage across sSA, range of sizes, risk vulnerability profiles and breadth of illustrative blockages and opportunities for risk-sensitive development. The analysis of these four cities illustrates the diversity of risk management capacity in both large and small sSA cities, but also point to some general trends and agendas for action. Smaller urban centres $(<500,000$ inhabitants) such as Karonga contain nearly half of sub-Saharan Africa's urban population, and are anticipated to experience a major portion of all future urban growth [3]. It is well known that many large cities such as Nairobi concentrate risks which need to be better understood, yet many of the future challenges for risk reduction will also be concentrated in smaller urban centres, which are often experiencing rapid growth [7]. It is in such contexts where the 
capacity to effectively plan for urban growth, proactively manage risk, and adapt to emerging natural and man-made hazards are considerably limited and where growth often outstrips infrastructure and service provision $[7,8]$.

Section 2 presents a common analytical framework to help identify blockages and opportunities for a transition towards a risk-sensitive and transformative urban development. This framework was initially proposed in Pelling et al. [5] and is further developed and applied in this paper through detailed investigations of blockages and opportunities to transition based on synthesised empirical research undertaken in the four key cities under the Urban ARK programme since 2015. The framework is illustrated through each city in turn: Karonga, Ibadan, Niamey and Nairobi. A concluding discussion reflects on city observations to draw out recommendations for city level and wider action and research partnerships.

\section{Blockages and Opportunities for Transition towards a Risk-Sensitive and Transformative Urban Development}

Risk management continues to remain a policy archipelago, distanced from the mainstream of development activity and strategy. This is as much the case for urban planners, private sector developers, artisan builders and community level or traditional leaders where budget, regulatory limits and a focus on short-term benefit constrains action, even when need is recognised. Diverse visions of the potentialities and limits of urban futures have emerged through the urban politics of climate change and disaster risk [9]. How can research work in partnership with practitioners and stakeholders at risk to support a transition towards a more integrated vision, process and practice of risk management? Figure 1 identifies three key blockages to this transition and three opportunities drawing from recent research under the Urban ARK programme in sSA [5]. The figure shows that transition is constrained by fragmented governance, donor priorities and inadequate monitoring of hazards, impacts and vulnerability.

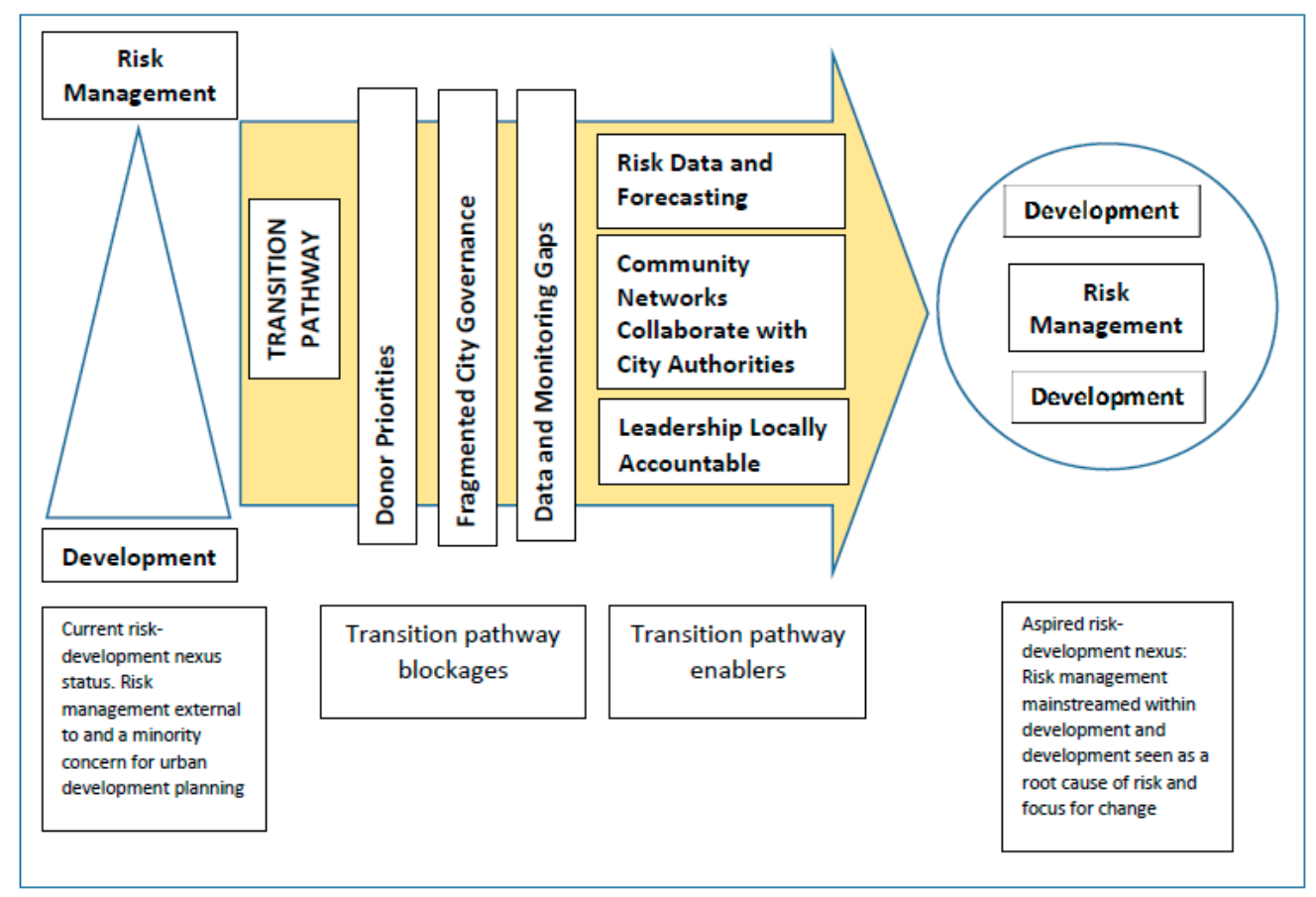

Figure 1. Blockages and opportunities for urban risk transitions. (Source: Pelling et al., 2017 [5]).

While there is no formal agreed upon definition, transformative urban development implies a radical or profound non-linear change to systems and shifts to new modes of urban planning, management and governance, thereby leading to new development pathways and practices that 
challenge the status quo [10-12]. Building on this, Revi et al. [12] (p. 13) propose that effective city-based disaster risk management and risk reduction provides a strong foundation for transformative urban development and adaptation, which also necessarily entails "effective multi-level urban risk governance, alignment of policies and incentives, strengthened local government and community adaptation capacity, synergies with the private sector and appropriate financing and institutional development." These issues are explored in this paper through the application of our conceptual framework presented in Figure 1, where they are presented as inter-linked blockages and opportunities for risk-sensitive and transformative urban development. Revi et al. [12] argue further that opportunities for transformative urban development and adaptation are high in many rapidly growing cities where much infrastructure and institutional architecture are still being developed, yet there is still somewhat limited evidence of how this is being achieved in practice. This paper investigates key constraints to achieving this in practice but also highlights important opportunities where pockets of transformative urban development are beginning to emerge in practice.

Institutional gaps relating to weak capacities, inadequate resources, lack of systematic co-ordination and divisions between formal and informal systems are a priority blockage to overcome for addressing the incompleteness of data and weak data collection mechanisms in urban sSA. In many cases, cities and communities do not have systematic loss records that are gender disaggregated or georeferenced. As such, the evidence base for correlating development drivers with risk through loss analysis is constrained. Hazard monitoring capabilities are often weak and emergent hazards (e.g., heat stress), as well as compound hazards, remain poorly understood in many cases. Considerable gaps remain in government agencies, civil society and policy leadership in terms of 'owning' specific hazards and related ameliorative interventions [5].

Effective practices and policies in urban planning and governance in reducing risk are considerably less well documented than the reasons for ineffective planning systems and local governments in post-colonial African cities [13]. This paper responds to Adelekan et al.'s call to address this gap through highlighting examples of effective partnerships between city governments, local populations and civil society organisations (e.g., Nairobi Mukuru SPA documented in Section 3.3) that address gaps in the risk-development nexus through simultaneously reducing risk and building broader societal transformation and urban development. Ajibade et al. [14] asked 'who are the dominant actors that can trigger a transition' and whether transition windows (e.g., political and institutional change) can be utilised to enhance equity and future risk reduction. In this paper, we show how opportunities for transition arise through several channels, notably through effective multi-level governance where organised civil society collaborates with the city government and other actors in networked arrangements [5]. The recent increase in citizen-led approaches for data collection, monitoring, recording of events and online data management is critical for advancing early warning on hazards, but often these initiatives remain limited to larger cities [2,5]. However, these transitions can be constrained by several factors such as in contexts where effective risk data and forecasting mechanisms and capacities are not present.

Political and institutional change can trigger processes of transition and transformation $[15,16]$. Transitions theory strongly recognises that innovations and experimentation in multi-level governance can offer the potential for transition [14]. Effective multi-level governance of climate change and disaster risk internationally is a significant shift in decision-making that can help break cycles of risk accumulation. There is also major opportunity for transition through the actions of networked civil society in many sSA cities, for example through Shack and Slum Dwellers International (SDI) [17] that are driving demand-led and inclusive planning for risk (see below for Nairobi case). There is further scope for transition if development donors partner with and provide finance opportunities to such independent actors at scale. This can support a transitional pathway of bringing power back to the city and invoke transformative shifts in power relations, accountability and recognised priorities for the city. However, the constant interplay between actors and decision-making processes are continuously negotiated through unequal power relations and spheres of influence and situated within the constraints imposed by broader political 
economic forces, which can disrupt transitions [14,18]. In cases where multi-level governance remains constrained, fragmentation between key state and non-state actors is often prominent, with top-down agendas often shaping city's decisions-with inadequate attention to local risk management priorities and everyday development failures. Fundamental shifts in institutional thinking are also required from predominant disaster-focused, short-term views to longer-term perspectives that emphasise vulnerability reduction, addressing root causes and equity considerations $[19,20]$. However, as Conway and Schipper's Ethiopian-based study [19] (p. 235) shows, this is challenging to achieve "precisely because many institutions have been specifically set up to respond to emergencies, including food aid, whose raison-d'être is put into question by a new approach".

Using the above framework as a critical lens, the paper now considers blockages and opportunities for transition towards risk-sensitive and transformative urban development through the four case study cities-Karonga, Ibadan, Nairobi and Niamey. The paper by Dodman et al. [21] provides a detailed overview of the spectrum of methods used across the programme for understanding the spectrum of risks in each study city. A major focus for the programme has been on strengthening the understanding of urban risk through developing data and information of policy with practical relevance to urban decision makers at all scales. To achieve this, a range of approaches were used in each city with emphasis on engagement with city stakeholders for evidence generation [21]. For this paper, authors have synthesised findings from studies in each city where multiple data types and results from a range of methods are used. These include documentary and institutional analysis, community data and participatory approaches (e.g., community led risk assessment and resource mapping), as well as surveys and interviews for the four city cases. The city cases introduced above are based on the following core questions, guided by the theoretical framing in Figure 1: How is risk currently managed by the city? What are the donor priorities, city governance structure and data and monitoring gaps? What are the barriers to transition and pathways to transition, particularly related to risk data and forecasting, community networks collaboration with city authorities, and locally accountable leadership? As noted, the city cases provide regional coverage across SSA to provide comparative insights into the diversity of risk management capacity in both large and small sSA cities, while also identifying some general themes and points for action.

\section{Transition in the Risk-Development Nexus-City Cases}

Guided by the theoretical framing summarised in Figure 1, Table 1 presents a summary of key findings for each city relating to governance contexts, data and monitoring, donor priorities and opportunities for transition in the risk-development nexus. Sections 3.1-3.4 explore these findings in detail with illustrative examples for each city in turn. 
Table 1. Summary of key city findings for transition in the risk-development nexus.

\begin{tabular}{|c|c|c|c|c|}
\hline City & Governance Context & Data and Monitoring & Donor Priorities & $\begin{array}{l}\text { Opportunities for Transition } \\
\text { in Risk-Development Nexus }\end{array}$ \\
\hline Karonga & $\begin{array}{l}\text {-Dysfunctional urban } \\
\text { local government. } \\
\text {-Lack of political attention and } \\
\text { finance for development. } \\
\text {-Limited co-ordination } \\
\text { between multiple internal and } \\
\text { external state and } \\
\text { non-state actors. } \\
\text {-Poor policy implementation. } \\
\text {-Fragmented top-down } \\
\text { accountability, not responsive } \\
\text { to community needs. }\end{array}$ & $\begin{array}{l}\text {-No locally held systematic } \\
\text { records on urban disasters and } \\
\text { losses and weak monitoring. } \\
\text {-Lack of data disaggregation } \\
\text { across urban and } \\
\text { rural settlements. } \\
\text {-Local government } \\
\text { under-staffed and } \\
\text { low capacity. }\end{array}$ & $\begin{array}{l}\text {-NGOs and donors set and } \\
\text { drive development agendas } \\
\text { and significantly shape DRM. } \\
\text {-Increasing but poorly } \\
\text { coordinated interest in } \\
\text { urban issues. }\end{array}$ & $\begin{array}{l}\text {-Partnerships established } \\
\text { between state and non-state } \\
\text { actors increasingly provide } \\
\text { essential infrastructure, } \\
\text { services and DRR } \\
\text { interventions. } \\
\text {-Community data collection and } \\
\text { monitoring e.g., through Urban } \\
\text { ARK Community Hubs. }\end{array}$ \\
\hline Ibadan & $\begin{array}{l}\text {-Weak and fragmented } \\
\text { implementation of DRR policy. } \\
\text {-Inadequate funding } \\
\text { mechanisms, weak local } \\
\text { government and unstable } \\
\text { political systems. } \\
\text {-Limited inter-agency } \\
\text { co-ordination. } \\
\text {-Fragmentation and } \\
\text { overlapping responsibilities } \\
\text { across government ministries } \\
\text { and agencies. }\end{array}$ & $\begin{array}{l}\text {-Lack of city-wide risk data } \\
\text { and monitoring. } \\
\text {-Risk data collection and } \\
\text { storage remain persistently } \\
\text { poor, particularly at lower } \\
\text { levels (i.e., wards } \\
\text { and localities) }\end{array}$ & $\begin{array}{l}\text {-Major role of donors in } \\
\text { addressing disaster risks, but } \\
\text { often not aligned with } \\
\text { local priorities. }\end{array}$ & $\begin{array}{l}\text {-City-wide risk data collected } \\
\text { under Urban ARK (e.g., using } \\
\text { DesInventar methodology). } \\
\text { Resultant risk maps can be } \\
\text { used as decision support tools } \\
\text {-Local communities } \\
\text { increasingly engaged in } \\
\text { DRR interventions. } \\
\text {-lbadan Urban ARK } \\
\text { Stakeholders' Platform on } \\
\text { Risk Reduction-goal to } \\
\text { develop co-ordinated city risk } \\
\text { reduction action plan. }\end{array}$ \\
\hline
\end{tabular}

Table 1. Cont.

\begin{tabular}{|c|c|c|c|c|}
\hline City & Governance Context & Data and Monitoring & Donor Priorities & $\begin{array}{l}\text { Opportunities for Transition } \\
\text { in Risk-Development Nexus }\end{array}$ \\
\hline Nairobi & $\begin{array}{l}\text {-Limited risk management } \\
\text { capacity of local government } \\
\text {-Weak policy co-ordination } \\
\text { implementation and } \\
\text { enforcement } \\
\text {-Lack of clarity in roles and } \\
\text { responsibilities within the } \\
\text { devolved governance structure. }\end{array}$ & $\begin{array}{l}\text {-Inadequate data on everyday } \\
\text { and large-scale disasters } \\
\text { available in appropriate and } \\
\text { accessible formats for } \\
\text { all stakeholders. } \\
\text {-Multiple research initiatives } \\
\text { to develop data but } \\
\text { fragmented efforts }\end{array}$ & $\begin{array}{l}\text {-Many external development } \\
\text { actors influencing DRM, } \\
\text { yet often fragmented and } \\
\text { duplicated efforts, } \\
\text { and misaligned with } \\
\text { local priorities. } \\
\text {-Lack of engagement and } \\
\text { monitoring beyond } \\
\text { funding lifecycles }\end{array}$ & $\begin{array}{l}\text {-Detailed risk data collected by } \\
\text { organised civil society through } \\
\text { community profiling and } \\
\text { mapping (e.g., through SDI). } \\
\text {-Longstanding data collection } \\
\text { on spectrum of risks led by local } \\
\text { and international research } \\
\text { institutes can support DRR } \\
\text { policy and decision making. } \\
\text {-Organised community } \\
\text { associations opening } \\
\text { opportunities for transition } \\
\text { through mobilisation and } \\
\text { advocacy campaigns and } \\
\text { partnering with local } \\
\text { government (e.g., Mukuru SPA) } \\
\text {-Nairobi Urban Risk } \\
\text { Partnership-potential for } \\
\text { mainstreaming and } \\
\text { coordinating DRR, led by NCC. }\end{array}$ \\
\hline Niamey & $\begin{array}{l}\text {-Limited co-ordination among } \\
\text { large number of fragmented } \\
\text { actors at national, local and in } \\
\text { traditional government. }\end{array}$ & $\begin{array}{l}\text {-Several research initiatives to } \\
\text { develop data. } \\
\text { Requires coordination. }\end{array}$ & $\begin{array}{l}\text {-Donor interest in urban } \\
\text { development, but not aligned } \\
\text { with dwellers main concerns. } \\
\text {-Lack of state oversight and } \\
\text { monitoring for } \\
\text { donor programmes. }\end{array}$ & $\begin{array}{l}\text {-Recently introduced } \\
\text { DRR-related policies and } \\
\text { initiatives (e.g., Ministry for } \\
\text { Disasters and } \\
\text { Humanitarian Action) } \\
\text {-Increasingly active } \\
\text { self-organised community } \\
\text { groups and lobbying } \\
\text { of government. }\end{array}$ \\
\hline
\end{tabular}

\subsection{Karonga, Malawi}

The small, but rapidly growing urban centre of Karonga (Karonga Town) is located on the shores of Lake Malawi in the north of the country. Karonga's population is projected to increase from 41,000 inhabitants in 2008 to approximately 63,000 in 2018 [22]. The Town is vulnerable to multiple everyday, small and large disaster risks and has been affected by earthquakes, drought and floods [8,22]. Everyday risks such as poor quality and inadequate sanitation and unsafe water also pose significant threats for inhabitants [23]. However, the nature and scale of risks in Karonga remains poorly understood and knowledge of vulnerabilities to disaster risks remain low [24]. This is partly attributable to the lack of political attention and 
finance towards the development and governance of small, but often rapidly growing towns throughout Malawi and indeed other sSA contexts more broadly [22].

Decentralisation was reintroduced in Malawi following multi-party elections in 1994 with many roles and responsibilities consequently devolved to the lowest level of government. Disaster risk governance in Karonga Town faces considerable challenges. Firstly, the Town's rapid growth has led to a growing demand for services and risk reducing infrastructure, yet provision is constrained by limited capacities and funding within local government [23]. As with other urban centres in Malawi and across sSA, growth in Karonga is largely informal, except in the commercial centre [8]. Secondly, the local government-the Town Council-was dissolved in 2009, resulting in the Town being governed by the rural local government-the Karonga District Council. Overall, it is apparent that the rural Karonga District Council is significantly over-stretched by its mandate for governing urban development challenges, particularly due to inadequate revenue and limited direct support from the central government. This weak governance structure has resulted in poor planning and project implementation throughout the Town. There is also a lack of clear understanding and consideration of context-specific urban issues such as market fires and floods [22]. As such, risk tends to accumulate in the absence of capacity and training on urban challenges and lack of clarity on roles and responsibilities.

A further major constraint to disaster risk governance is that there are no locally held systematic records on urban disasters and losses for Karonga Town. The available district level data on urban disasters mainly covers large intensive disaster episodes such as earth quakes and large-scale floods. Systematic records for more localised disaster data across a broad spectrum of risks experienced in Karonga and other urban centres are either inadequate or non-existent. Some health records are available from the district hospital serving the wider region, but these require detailed analysis to extract the town-specific disease burdens, trends and vulnerabilities from the records of patients living in the town. Moreover, when disaster records are in place, these are often inadequately accounted for. For example, Karonga Town registered the largest number of disasters in Malawi between 1946 and 2008, which although accounted for in district and other available data sets, is not well recognised in planning or policy [25].

More systematic disaggregated data at the sub-district level on social demographics and disaster losses (especially from extensive and everyday risks) is necessary for effective local policy formulation and planning.

Following extensive flooding in southern Malawi in January 2015, national and international development partners have committed to assisting the country in its response strategy. However, this was subject to a conducive policy framework being in place. As such, Malawi published its Disaster Risk Management Policy (DRM) in 2015 following significant pressure from national and international development partners and donors. The approval of the policy helped to unlock considerable donor funding. For example, the World Bank committed over $\$ 40$ million for the Malawi Flood Emergency Recovery Programme (MFERP) [26]. This situation does not reflect a one-off event, but rather exemplifies the nature of policy and practice of urban planning in Malawi and indeed many cities in SSA, which are largely influenced by external agents. The policy assigns a crucial role to decentralised governance structures from village through district to the national levels for disaster risk reduction efforts. However, the policy has some notable weaknesses that are limiting effective implementation. For instance, Malawi's urban areas are not specifically addressed despite the increasing trend of urban disasters such as flooding and resource allocation to lower governance scales being highly inadequate [24]. Furthermore, the disaster management structures included in the Disaster Risk Management Policy exist largely only on paper with limited capacity and practical knowledge for addressing risks and risk accumulation.

The respective priorities of donors including external governments, non-governmental organisations (NGOs) and development agencies, as well as the national government all play a significant role in shaping DRM agendas at all scales. The Malawi Government has received major loans from multiple international agencies such as the African Development Bank (AfDB) and World 
Bank (WB), which are used for various development initiatives that have co-benefits for addressing disaster risks, such as sanitary facilities and drainage infrastructure provision. Yet, these loans have created large-scale debts. As a result, new alternative partnership arrangements are increasingly being established between the private sector, public utilities, micro-finance institutions and NGOs to support local governments in providing essential infrastructure and services [26].

The implementation of policy in Karonga Town tends to be externally driven in terms of funding and capacity building. The national government acts both to direct policy and support implementation. Policy directives are usually given from the central to local levels. Policy implementation tends to focus on response to disaster events such as the distribution of relief items to those communities living in risk zones. Very little attempt is made to proactively reduce risks either through capacity building or infrastructure upgrading. The risk reduction efforts that are in place such as for flooding and fires are largely a result of donor contributions. Moreover, local communities perceive civil society actors as the key policy agents and collaborate with them often instead of their local governments [22].

Transparency is embedded in the DRM policy through its provisions for accountability within decentralised governance systems. However, in practice the decentralised accountability ladder from the national level through to community levels is disconnected and fragmented. Accountability occurs separately between state actors on the one hand and between community groups and their traditional leaders on the other, with both channels experiencing challenges and conflicts. City officials are mandated to report to national policy makers. Accountability at the city level is expected through the ward councillors, but there are no such wards in place in the case of Karonga Town [8]. Instead, ward councillors report to the citizens through traditional leaders. NGOs who have presence in the community play an intermediate or bridging role and participate in the local government meetings through the District Executive Committees (DEC). Sometimes, the DEC meetings are directly funded by the NGOs. This points to the ongoing prominent influence that NGOs have in shaping policy and practice under conditions of funding constraints faced by local governments for developing and implementing policy and democratic decision making. The independence of the DECs is essential for community-led prioritisation of issues, but there is the risk that NGOs could be setting and monopolising the development agenda and compromising the mandate of legally constituted participation spaces.

The 2015 DRM policy provides for interaction between communities and Councils through the decentralised reporting mechanism. Under this mechanism, the lowest level is the village DRM committee, followed by the Area DRM, the District DRM Committee and the National Platform at the highest level. This policy provision is a replica of the Decentralisation Policy of 1998 which seeks to entrench democracy in policy and decision-making. In practice, these committees do not have a specific urban focus. As noted, rural (Village) committees are in place in Karonga Town due to the local government dissolution in 2009. However, even in other towns and cities, such as Mzuzu City (also a small urban centre with a population of under 200,000 in Northern Malawi), where the local government exists, only city-wide DRM-Committees (counterpart of District DRM) have been established. In such cases, there are no designated officials or actors for direct policy or local community engagement at the sub-city level. Recognising this gap, Urban ARK team members based at Mzuzu University, recruited a team of Community (research) Counterparts in 2015 to provide such an interface between the local government and community. This interface has demonstrated considerable potential for meaningful collaboration between local government, community members and researchers and for supporting an informed and organised citizenry at minimal cost. In Mzuzu, the Urban ARK team based at Mzuzu University went as far as establishing the DRM Committee in one neighbourhood (in the Zolozolo West Ward) on behalf of the local government, both to create an entry point for the research but also to support a governance structure provided for by the DRM Policy. The DRM Committee has now become the locus of interaction between the city and community with the potential for upscaling citywide. The DRM Committee meets on a regular basis and is a significant platform for interaction and information sharing between researchers, local government representatives 
and community members. Recently established local Community Hubs under Urban ARK offer further potential for supporting effective risk sensitive development. Decentralised Community Hubs have been established in Karonga, Malawi (as well as Freetown, Sierra Leone) in partnership with local partners Mzuzu University, Malawi and Sierra Leone Urban Research Centre (SLURC) in Freetown who co-ordinate and lead the Hubs. The Hubs are centres for learning and co-ordinating community actions and programmes resulting from participatory risk mapping and assessment work in the two urban centres. These Hubs have considerable societal impact as they involve a significant training element with community members on participatory risk mapping and other methods, as well as capacity building workshops.

Despite these opportunities, mainstreaming DRR for various hazards and a transition towards risk sensitive development remains a significant challenge in Karonga due to multiple interacting factors including the absence of a functional urban local government, inadequate financing, inherent failures to plan and regulate growth and silo-based approaches [24]. Karonga's rapid growth adds urgency to resolve these and other challenges that are limiting risk reduction and transformative development.

\subsection{Ibadan, Nigeria}

The city of Ibadan, the capital of Oyo State in Nigeria is the largest traditional urban centre in sub-Saharan Africa. It has one of the highest population densities in the country, with considerable annual population growth [27]. This increasing population concentration is occurring largely in informal/unplanned areas and without a commensurate increase in critical urban infrastructure and services. Residents of Ibadan are exposed to a range of hazards and risks including windstorms, flooding, fires, communicable and infectious diseases, road accidents and violent crime $[27,28]$. The management of risk in Ibadan is to a large extent guided by the National Disaster Management Framework (2010), together with the priorities, capacities and resources available to the relevant state government ministries and agencies, civil society organisations and development partners. A National Policy on Disaster Risk Reduction (2017) was only recently formulated. The policy recommends that disaster management in the country must be government-led and co-ordinated, have a multi-agency approach and incorporate development partners, CSOs and NGOs. The policy has also highlighted co-ordination of disaster risk reduction initiatives within a unified policy framework in a proactive manner at all levels of Government, yet implementation remains weak and fragmented [20].

As a discrete policy area, the portfolio of risk management in the city is undertaken by the Oyo State Emergency Management Agency (OYSEMA). The activities of the Agency are governed by the National Disaster Management Framework (2010) which mandates all State Emergency Agencies in Nigeria to prepare for, prevent, mitigate, respond to, and recover from disaster events. This also includes collating data on disaster events. However, OYSEMA has functioned largely in a reactive capacity and as a co-ordinating agency during small or large-scale disaster events. In this regard, OYSEMA collaborates with the National Emergency Management Agency, State Ministry of Environment and Water Resources, Fire Service, Federal Road Safety Corps (FRSC), security agencies and Nigeria Red Cross Society. The Agency is the co-ordinating body for flood emergency situations (State Law 2008, Gazette, Vol. 34 No. 4, 19 February 2009). However, the ruling government largely determines how the agency functions. While the law that established OYSEMA requires each of the 11 Local Government Areas in the city to establish Local Emergency Management Committees (LEMCs) to mainstream disaster risk reduction activities citywide, Olaniyan et al.'s (2018) study found that the level of compliance has been extremely poor and that these LEMCs are largely non-existent. This is due to inadequate funding mechanisms, weak local government and unstable political systems [21].

A state platform for Disaster Risk Reduction comprising stakeholders from state government ministries and agencies, faith based organisations, NGOs/CSOs and CBOs was inaugurated in 2008 to formulate policy towards disaster risk reduction in the state and by extension the city. Nonetheless, this is yet to be actualised and there is still no policy to integrate risk reduction into development planning. However, an emergency response/contingency plan has been recently developed (OYSEMA, 
2013). Overall, attempts to manage everyday and other risks in the city are pursued through several channels. State ministries, departments and agencies (e.g., bureau of physical planning and development control, health, environment and water resources, Nigeria Security and Civil Defence Corps, Department of Fire Service) have a central responsibility for disaster risk management. Nevertheless, the degree to which this is achieved varies from one ministry/agency to another depending on financing and capacity. The ministry of health, for example, has different programs supported by international donors which aid to address public health risks (e.g., malaria, tuberculosis), yet there is a significant lack of mainstreaming and co-ordination of interventions across sectors for linked DRR efforts.

NGOs and civil society organisations also play a key role in addressing disaster risks across the city. For example, the Nigeria Red Cross Society (NRCS) was established in 1960 by an act of parliament with the mandate to provide physical and psychological assistance to citizens, especially during disasters. The NRCS is a major collaborator with the city government particularly regarding emergency response. The NRCS conducts preliminary risk assessments of sites and locations prone to disasters in the city and leads community sensitisation measures to support disaster prevention and preparedness. Funding received from donors is also deployed to facilitate the activities of Red Cross volunteers which contribute to addressing gaps in risk governance. The effectiveness of the NCRS in carrying out its statutory responsibility of preventing and managing disasters in the city is significantly influenced by the support received from the state government and other international and local donor agencies. Support from government has dwindled over the years and is especially dependent on the disposition of the governor at any given period.

Major risk management-related programs undertaken by different government ministries and agencies within the city are principally informed by donor priorities and resources. This is due to low public financing, knowledge gaps and the inadequate capacity of staff in government departments. Furthermore, local governments still depend on the federal and state governments for funding. For the most part, funding decisions are influenced by complex political motives including political affiliations of local populations and loyalty of local government administrators to higher level government functionaries, among others. There is also limited inter-agency co-ordination, fragmentation and overlapping responsibilities across the various government ministries and agencies in risk management. Consequently, the city government faces considerable challenges in fulfilling its mandates, including those related to risk management.

Donors, therefore, play a major role in determining risks that receive attention and the extent to which these are addressed. An on-going example is the first deliberate engagement in city-wide flood risk management; the Ibadan Urban Flood Management Project (IUFMP). This was formed at the recommendation of the Global Facility for Disaster Reduction and Recovery (GFDRR) following the 2011 Ibadan flood disaster which highlighted the urgent need for an urban flood risk assessment and management program. Prior to 2011, the city had experienced several flood events, including major flood disasters [20]. The IUFMP is shaped by Pillar 2 of the World Bank's Africa Strategy which addresses vulnerability and resilience, and the World Bank/Nigeria Country Partnership Strategy (2014-2017) climate change (resilience) agenda which is open to provide support to improving the resilience of urban centers to natural disasters (IBRD 2014). Although the State government request through the Federal government was for a credit facility to address infrastructural challenges encountered resulting from the 2011 Ibadan floods, World Bank approved the following flood risk management measures:

i. Assessment of flood risk in the city, planning risk reduction measures, and financing of preventive structural and non-structural measures to enhance flood preparedness (preparation of urban, drainage and solid waste master plans).

ii. Financing public infrastructure investments for flood mitigation and drainage improvements.

iii. Improvement of institutional co-ordination on flood risk management in Ibadan. 
Whereas the State government identified 48 river canals in need of dredging and widening for effective run-off discharges, only 36 were approved for funding by the World Bank. Forty other communities of flood-prone areas which did not benefit from the donor support of dredging rivers continue to advocate the government for assistance in this regard. Similarly, the inability of the government to successfully address the considerably low coverage of water supply and sanitation in the city is being aided by the African Development Bank Urban Water Supply and Sanitation Project for the city. However, the project covers only the high density residential areas and peri-urban parts of the city. Evidently, flood risk management has received much attention relative to other disaster risks and everyday hazards (e.g., fire hazards, violence, crime and road traffic accidents) because these have not acquired the status of large scale disasters or do not fall under the funding priorities of international development and donor agencies. Nonetheless, the cumulative impacts of such events are overwhelming [27].

Risk data collection and storage remain persistently poor in Ibadan, as in other Nigerian cities. City data for all purposes (social and economic), where available, is mainly provided at the level of LGAs. Non-availability of housing and population census data at lower levels (i.e., wards and localities) remains a significant challenge for vulnerability and risk assessment for the city. Inventory of risk-related events across the city is poor and mainly limited to events with significant impacts. There is also the issue of incomplete and sporadic record keeping of risk-related data by the government and relevant city agents. Monitoring is neither regular nor systematic and is mainly undertaken for a specific need rather than on a routine basis. Manual record keeping by city government is also prone to loss or misplacement. The lack of city-wide risk data covering the whole spectrum of risks is a key limitation to informed decision making for risk management and development planning. To address this gap, the Urban ARK Ibadan city programme has systematically worked to collect city-wide data on everyday risks, and small and large disasters at the ward level for the city using multiple methods including the DesInventar methodology and household/community level assessment and understanding of urban risks through engagements/consultations with public agents (city officials), household surveys and focus group discussions with community members. The development of risk maps at the ward scale based on analysis of this data have the potential to be used as decision support tools for city authorities.

Community Development Associations (CDAs) are involved in risk management in the city through various self-help activities within wards and localities (e.g., infrastructural development, management and maintenance of roads, water supply, purchase and repair of electricity transformers, sanitation, flood and erosion control, and security enforcement). Community members also play a role in the monitoring and enforcement of regulations and guidelines geared towards risk reduction e.g., not building on flood plains and the prohibition of dumping of solid waste in drainage channels. Communities are also increasingly engaged in disaster rescue missions and disaster risk reduction activities. For example, traditional rulers, community leaders and leaders of CDAs and CBOs (e.g., market associations) have been actively engaged in stakeholders' meetings during deliberation on risk issues (e.g., Ibadan Urban Flood Management Project stakeholders' meetings). However, collective influence is more constrained and not at the same scale as in the case of Nairobi discussed above, for example, where there is a very strong federation presence that supports advocacy and influence of organised civil society at scale.

The Urban ARK Ibadan city programme has deliberately initiated the process for enabling risk transitions in the city by organising stakeholder meetings which have brought together community leaders, trade associations, city officials, NGOs, CSOs and researchers in group discussions including the Urban ARK city project inception/launch workshop (2015), working group sessions and meetings of the Urban ARK Stakeholders' Platform on Risk Reduction in Ibadan (2018). These forums have enabled the collaborative identification of stresses facing the city and the key everyday hazards and disasters (shocks) from the wide spectrum of risks. The primary goal of the Stakeholders' Platform on Risk Reduction which adopts a multi-staged process, is to develop a co-ordinated plan of action 
for risk reduction in the city, highlighting the most appropriate actions, responsible actors and roles for identified and prioritised risks based on the knowledge gained in the risk assessment process and local context. This is a considerable opportunity for supporting transition in the risk development nexus in Ibadan and has been strongly supported by stakeholders. But the initiative will require ongoing advocacy, engagement and support in an already constrained institutional environment as described above.

\subsection{Nairobi, Kenya}

Nairobi is a large and rapidly growing city; the second largest in the East Africa region, with considerable regional economic and political significance. The majority of Nairobi's over 3.3 million population live in informal/unplanned areas, typically densely populated, low lying and flood prone with very limited basic services and infrastructure. Poverty, food insecurity and other environmental vulnerabilities are widespread. These challenges are compounded by multiple interacting shocks and stressors such as disease outbreaks. Nairobi's social, political and physical environments are characterised by vast inequalities and injustices [29]. Rapid, fragmented and unplanned urbanisation has led to increased flood risk across the city. Weak governance and consequent poor service delivery have exacerbated man-made hazards such as poor solid waste management, resulting in widespread unsafe disposal, with significant negative health impacts, including the proliferation of infectious and non-communicable diseases, environmental degradation and greenhouse gas emissions [30]. This is typified by the Dandora municipal open dumpsite located close to public institutions, posing a range of health risks to the over 250,000 people estimated to be living adjacent to the site, in addition to causing extensive environmental damage [31].

Effective urban planning has proven a major challenge in the city. As Myers [29] (p. 44) explains "urban environmental planning in Nairobi has often been ambitious, but financially and politically unworkable". As such, the risk-development nexus; the complex interlinkages and gaps between risk management and development, is underpinned by competing demands, resource constraints and inadequate capacity of local government. To further characterise the risk-development nexus: "the way in which urban growth and expansion are planned and managed is what largely determines the extent and distribution of risk" [13] (p. 37). Climate risks and vulnerabilities are increasingly well recognised in the city, with several recent developments such as the Rockefeller 100 Resilient City status providing some impetus. There is considerable awareness and increasing willingness for change among key city actors including risk managers and urban planners [5]. However, as with many other sSA contexts, risk management remains limited and constrained by weak co-ordination between all sectors and scales of governance, as well as complex policy landscapes where implementation and enforcement are widely lacking. There is also a need to better understand interactions and cascading effects between different hazard and risk types in Nairobi and their potential effect on infrastructure and development. The tensions between formal and informal planning systems and governance arrangements also require urgent attention, particularly due to the vast extent of unplanned settlements in the city. Key additional challenges for transition in risk management include fragmented civil society, ongoing tensions between diverse city actors and hierarchical decision-making that overlooks local risk management priorities and addresses everyday development failures.

Disaster risk management in Nairobi is highly complex and cross-cutting, with an ongoing lack of clarity in roles and responsibilities within the devolved governance structure. The devolved system of governance in Kenya came into effect in 2010 when the new Constitution of Kenya (CoK, 2010) was adopted and shifted away from a centralised system. Under the Constitution there are two overarching levels of governance-National and County government. These are created on an equal basis-they are distinct but are required to work in harmony [32]. They also have the power to secure resources, control their own budgets and raise revenues. Nairobi City County (NCC) is further devolved into sub-county, ward and village levels. Within this formal structure, the chieftancy plays a key role (albeit informally and contested in many cases) in linking communities with the lowest level of government, particularly in informal settlements which are often divided according to tribal 
affiliation [33]. The sub counties and wards are the focal points of service delivery. The devolved system of governance has proved complex with ongoing challenges, fragmentation and conflicts across all governance scales. The Constitution recognises disaster risk management as a developmental challenge that should be addressed through both county and national government levels, as well as local levels [34]. A Draft National Policy of Disaster Management (DRM Policy, 2009) was formulated in 2009 with the intention of clearly identifying institutional mechanisms and responsibilities for DRR and unifying existing ad hoc policies relating to DRM in the country. However, almost a decade later this is still awaiting cabinet approval and thus co-ordination challenges remain across all levels as well as continued ambiguity over mandates and responsibilities. A further constraint on DRR in Kenya is that the national budget priorities continue to focus on disaster relief and poster-disaster response [34]. In the absence of an overarching national policy, Nairobi County enacted a disaster management and firefighting policy in 2015, which has created some clarity in DRR mechanisms, but implementation has proved challenging to date.

Transition pathways are evidenced in emergent innovative and inclusive approaches to governance and development, with risk reduction co-benefits and opportunities beginning to transpire across the city. This is increasingly occurring through the collective actions of networked civil society, often in collaboration with local government and other actors. Particularly notable leadership has been through organised community associations opening opportunities for transition. For example, the Kenyan slum-dweller federation Muungano wa Wanavijiji led a mobilisation and advocacy campaign, with technical assistance from Akiba Mashinani Trust (AMT) and staff at SDI-Kenya (SDI-K), which led to the designation of the Mukuru informal settlement Special Planning Area (SPA). The Nairobi City County designated the SPA in August 2017. Interdisciplinary consortia including academic, government, private-sector, and civil society actors have synthesised data and generated policy briefs to inform planning strategies. In support of widespread participation in these planning strategies and due to the SPA's scale and complexity, Muungano has adopted innovative approaches to mobilise residents and collecting data, which have benefited from Urban-ARK support. Planning for the SPA will also help integrate risk management into securing land tenure and upgrading, and the redevelopment schemes through innovative multi-level governance and connecting community members across all levels of government. While the initiative is still in its early stages and many challenges remain, this is a notable transition in state-civil society relations in Nairobi and could serve as a catalyst for governance reform in other urban centres across sSA.

Additional innovation and potential for transition is evidenced at ward and local community scales where actors have taken advantage of existing structures to strengthen DRM and DRR. For example, at the local level, District Steering Committees have also assumed the role of Disaster Committees and in the absence of dedicated funding mechanisms for DRM at community scales, alternative sources are being drawn on to support DRR such as the Youth Enterprise Development Fund and the Women Development Fund [25]. A key challenge is ensuring that such innovative initiatives are recognised and supported as devolution continues to be implemented and DRM policy is approved. These initiatives are often cross-cutting and fall under broader development programmes, such as slum upgrading projects. Based on their research on slum upgrading in Kibera, Nairobi for Urban ARK; Mitra et al. [33] explain that such integrative approaches can become an important tool for strengthening resilience to risks such as flooding, conflict, and security through building trust between communities, government and other actors. They argue that "development interventions adopting an integrated, multi-sector, consultative approach have a stronger potential to increase resilience in multi-risk environments compared to single sector projects" [33] (p. 4).

Disaster risk governance in Nairobi is constrained by inadequate systematic data on everyday and large-scale disasters available in appropriate and accessible formats for all stakeholders, including practitioners and local communities. However, findings from Urban ARK research in Nairobi and other cities such as Freetown, Sierra Leone have highlighted the considerable potential and importance of drawing on detailed risk data collected by organised civil society through community profiling and 
mapping for identifying and acting on disaster risk [35,36]. For example, SDI have prepared detailed profiles and maps of informal settlements in Nairobi and use this information for supporting state engagement, which fills a large data gap at local government level. This has been a major factor in supporting the development of the SPA discussed above.

There is further opportunity for addressing the disaster risk data challenge through drawing on longstanding local data collection initiatives on risks, broader urbanisation processes, urban health and wellbeing statistics, especially for informal settlements in the city. These initiatives have been led by local, national and international research institutes such as the African Population and Health Research Center (APHRC) through the Nairobi Urban Health and Demographic Surveillance System (NUDHSS) from 2002 to date and the Nairobi Cross-sectional Slum Surveys in 2000 and 2012. These significant data sets and related research studies can support implementing agencies and local governments to identify priority risk areas across the city and support effective risk reduction and service delivery models [37].

In further recognition of the need to address fragmentation in DRM across Nairobi and to support integration across diverse actors, there have been recent calls from city actors, particularly the Nairobi City County to develop a shared platform for information sharing and collaboration. Significantly, the Nairobi Urban Risk Partnership was proposed at an exploratory meeting initiated and facilitated by Urban ARK at the African Population and Health Research Centre (APHRC), on 10 May 2017. This was in response to an identified need to address a major gap and need in the city for driving forward the disaster risk and resilience agenda and building a community of practice. The partnership was proposed by the City County Urban Planning Department and seconded by Departments of Security and Disaster Management, Housing and Urban Renewal, and the University of Nairobi. The partnership brings together stakeholders leading various urban risk efforts in the city and aims to ultimately inform the development of an urban risk management plan, pursuant to the Nairobi City County Disaster and Emergency Management Act (2015). A further aim is to mainstream disaster risk management planning in normative programs. There are many development actors that have influence development and risk agendas in the city including international donors and aid organisations, private sector, CBOs and NGOs, yet often these efforts are fragmented with considerable duplication of efforts. As such, the partnership is a useful central co-ordination body and information source for external funders and donors undertaking research and development interventions in the city. Overall, the partnership holds considerable potential for strengthening DRR and DRM in the city and improving co-ordination; however, sustained momentum is constrained by local government transition, competing political priorities and budget constraints. To help overcome this, a designated Nairobi-based partnership co-ordinator has been assigned and terms of reference have been drawn up by the NCC for facilitating partnership activities.

\subsection{Niamey, Niger}

Niamey is the state capital of Niger and has grown from 30,000 inhabitants in 1960 to over 1 million in 2012 [38]. It is one of the poorest cities in SSA and is growing rapidly with immigration from drought-prone rural districts characterised by widespread poverty and food insecurity [39]. Niamey is a multi-ethnic city, with seasonal and permanent migrants from across Niger, as well as nationals from neighbouring countries, Nigeria, Mali and Benin. Traditional livelihoods of agro-pastoralism have largely given way to the informal small-scale service sector income-generating activities in which the poor generally work. The city is facing increasing risks, principally flooding, public health issues and disease, as well as food insecurity [39]. These risks are exacerbated by widespread economic precariousness, increasing unemployment, delinquency, school dropouts and conflict in neighbouring countries. Poor land use planning and limited and weak infrastructure combined with mounting population pressure, principally due to rural-urban migration, have resulted in the increased occupation of flood-prone areas [39]. Many new migrants occupy sites that are vulnerable to flooding $[39,40]$. The associated risks are exacerbated by the variability and extremity of Africa's changing climate [41]. 
With a significant proportion of the city's population living in unplanned settlements and marginal land, the State of Niger has adopted a housing policy and sanctions to regulate development in an attempt to provide improved and adequate housing across the country. Several legislative and regulatory measures have been introduced (e.g., Law 2017-20 of 12 April 2017) to prohibit construction in risky areas and to establish related planning and operational planning procedures. However, implementation has been weak with continued unprecedented development of informal building and other practices that have exacerbated vulnerabilities across the urban risk landscape. While the original spatial extension from founding villages followed a planned layout, the liberalisation of the land market from 1997 onwards, combined with the lack of monitoring and control amplified informal practices regarding both access to land and building construction. Informal settlements and non-permanent traditional habitats have proliferated throughout the city, largely through informal or illegal subdivision of plots by traditional landholders. The city's risk landscape has been strongly shaped and exacerbated by these patterns and approaches to development.

Urban governance is shared between the state, local and regional authorities, traditional rulers, donors, and NGOs who often intervene in specific sectors (health, education, hygiene and sanitation); however, there is limited co-ordination and collaboration between these actors. Since 2000, Niamey has experienced an ongoing political decentralisation process, yet functions and responsibilities between local government, chiefs and central government at the local scale remain unclear with considerable overlap. The considerable instability and high staff turnover within the city leadership and other governmental levels has led to weak co-ordination and implementation of risk-related and development-related interventions. This fragmentation in governance results in a lack of accountability and monitoring of actions. The state is responsible for monitoring all risk and development-related projects, programmes and investments over the long-term or regulating the implementing organisation to undertake these actions. However, the state lacks resources to do this, and consequently, monitoring and evaluation of such initiatives are weak. A relevant example is the case of a recent large scale cadastral survey undertaken in Niamey by Agence Française de Développement. The operation came to a halt when the agency withdrew after the project duration with very little impact and the city continues to experience considerable and often unregulated expansion without considering the outcomes of the survey.

In most development projects and programmes, Niger relies heavily on the support of donors whose priorities often do not fundamentally align with urban dwellers' concerns. For example, while roads and sanitation are the major problems in the city, donors' principal interventions have been to finance the cadastral survey and draw up an urban plan. Yet, these cost-intensive operations have had little practical impact or developmental benefit, particularly due to the short-term nature of funding availability and lack of continued support for implementation and monitoring. Risk management capacity in Niamey is low with local authorities often depending on external aid and humanitarian structures to respond to emergencies. There are several major internationally funded programmes underway to address acute risks of food insecurity, floods and other issues. The most relevant example is the World Bank-funded Niger Disaster Risk Management and Urban Development Project [42] that includes flood risk management investments such as drainage, irrigation, dike construction and flood protection infrastructure, as well as the rehabilitation of watersheds in urban and rural areas, and capacity building for urban development and disaster risk management. Furthermore, to address food insecurity, the National Food Crisis Prevention and Management System has been created with supporting bodies such as the Co-ordination Unit of the Early Warning System and the Food Crisis Unit, all funded by multiple donors. However, there is poor co-ordination and communication between the donor funded initiatives and other initiatives described, with duplication of efforts and lack of monitoring remaining commonplace.

In recent years, there has been growing research attention on urban risks and strategies for their prevention in Niamey. For example, Urban ARK researchers from Abdou Moumouni University undertook an adapted household economy baseline study of vulnerability to flooding, as well as 
an inventory of small-scale disasters using DesInventar [40]. The Network on Hydrometeorological Risks in African cities (RHYVA) has also undertaken extensive studies on the causes of flooding in Niamey. Research centres such as the Agro-Hydrometeorological Centre (Agrhymet) and the African Centre for Applications of Meteorology for Development (ACMAD); the Niger Basin Authority (NBA) have also carried out work on the risks that led to the production of the very first river flood risk maps in the city of Niamey. Evidently, data on disaster risks, particularly flooding, does exist to some extent but there is a reluctance amongst many institutions to co-ordinate and consolidate data and make data openly accessible. For example, there is no standardised flood loss database for Niamey, yet multiple isolated individual studies indicate a dramatic increase in the frequency and intensity of floods observed in the city over the last decade $[40,43]$. The state has failed to ensure co-ordination and to support open access data, despite the importance of this for facilitating increased understanding among diverse stakeholders of a range of risks faced by the city and how they are changing. However, the recent creation of a ministry in charge of disasters and humanitarian action signals potential for greater co-ordination and improved risk prevention and disaster management in the city of Niamey.

At the neighbourhood-level, communities are increasingly self-organising and engaging with local authorities to help address local development and risk-related challenges. The most noteworthy actions are those of women's and young people's groups that are involved in addressing hygiene and sanitation issues. These activities are carried out under the patronage of the neighbourhood chiefs who are considered as local representatives of the administration. However, these activities are often undertaken on an ad hoc and unco-ordinated basis, with limited influence at scale. Community cohesion has also been facilitated by the establishment of security brigades in the different districts, which has helped to reduce theft and crime. Greater collaboration between the state and local communities would help to support disaster risk reduction across the city [44]. As Revi et al. [12] (p. 28) emphasise, it is critical to focus on and understand how linkages are established between local governments, community organisations, researchers and other urban actors in defining and then driving alternative forms of risk reduction, and that this "depends on city governments that can listen to citizen movements and see the validity of the living alternatives they offer".

Overall, risk reduction in Niamey is constrained by several key factors: Donors' priorities do not align with local priorities; urban governance is highly fragmented with unclear and sometimes conflicting roles and responsibilities between actors; data sets relating to flooding and other risks are fragmented, incomplete and sometimes contradictory with open access remaining a challenge; and monitoring and evaluation of risk-related interventions remains weak. The chronic instability and high turnover of senior municipal officials results in a lack of continuity in risk and development interventions and priorities. The overall lack of synergies described severely limits efforts to identify and manage risks effectively. These constraints notwithstanding, there is opportunity for movement towards transition and transformation in risk management and development through recent progressive policies and initiatives such as the creation of the Ministry for Disasters and Humanitarian Action and Risk and Disaster Management Program, as well as increasingly active self-organised community groups that are addressing key disaster issues at neighbourhood scales and lobbying the government.

\section{Concluding Discussion}

The increasing vulnerability of many African towns and cities to disasters has been increasingly recognised in recent years, due to multiple shared characteristics and underpinning socio-economic, political and cultural factors which have driven risk accumulation [45-47]. A significant proportion of current and future development will be concentrated in the towns and cities of sub-Saharan Africa. This offers vast potential but at the same time such development futures are intertwined with risks and losses from disaster events [2]. This paper has shown that contemporary risk management regimes in the four case study cities across SSA are characterised by considerable gaps and blockages for dealing with current and future risk, yet there are also several significant emerging opportunities and 
innovative initiatives for overcoming these barriers. These issues have been explored through the application of the conceptual framework presented in Figure 1 to understand processes of transition towards risk-sensitive and transformative urban development, and to engage with these processes as researchers and practitioners. The detailed analysis of urban risk governance, blockages and enablers across the four cities is an important contribution given the scale and rate of urbanisation and urban risk development worldwide, and particularly in Africa. In explaining urban disaster risk governance from these cases, the study contributes to an understanding of African cities beyond dominant 'Western' definitions of urban development. This also allows for a critical analysis of external interventions (international donors and NGOs) and their legacies in urban risk creation and reduction.

While recognising their diversity, sSA towns and cities are typically characterised by significant international and national donor presence, intertwined with complex governance structures including powerful traditional authorities, as well as increasing private sector activity and investment. The SDGs support an integrated approach to risk management that identifies urban development both as a driver and potential opportunity and solution to risk and loss. This paper has shown that efforts to address urban development and governance challenges can support risk reduction, as well as challenge underlying political and power relations between diverse urban actors. Urban risk governance includes all institutions that impact risk, not only formal administering and management of disaster risk [2]. This does not downgrade the importance of action by the formal institutions of the state (national and local governments and their associated agencies) but rather reflects the increasingly recognised principle of coproduction. In situations-such as those found in most African cities-where the state does not have the ability to provide all the necessary services to citizens, partnerships with non-state actors have been proven to increase the quality of state action in a way that enhances accountability and legitimacy $[48,49]$. The involvement of grassroots organisations, often rooted in activities such as women's savings groups, therefore extends democratic participation in urban development. The city examples have underscored that for transition and transformation in risk management to be achieved there is a need for clearer administrative procedures and integrative and inclusive governance that transcends formal and informal divisions. This will require a transition from fragmented governance to more joined up governance between civil society groups, city government, local universities, research institutions, and other urban actors. Indeed, as previously noted, transitions theory places emphasis on change being interconnected with innovation and shifting relationships between governance actors $[5,10]$.

While the case studies have revealed considerable fragmentation and a lack of co-ordination in urban risk governance landscapes, there is also clear evidence of increasingly joined-up and demand-led governance, as illustrated by the Nairobi Mukuru SPA example. Here, an innovative, forward looking and collaborative governance transition is being driven by communities and stakeholders occupying informal settlements, where much urban growth will continue to occur. This, and other examples such as District Committee formation in Karonga, show significant potential for a transition towards progressive multi-level risk governance through collective action-with organised civil society working with supportive city authorities and other actors in productive and strategic ways, whilst maintaining independence.

There appears to be increasing willingness from both civil society, NGOs and local government to collaborate over resilience building, disaster risk reduction efforts and the recognition of the limits of acting alone under resource and capacity constraints. As Fraser et al. [5] (p. 108) argue, "holism and partnership are necessary to bring risk and development together in ways that address multiple everyday risks and the linkages across levels and scale that define urban risks for people". However, there is also some concern that risk accumulation could be exacerbated by the involvement of external actors and donor funding, particularly where priorities are not aligned, as discussed in the cases of Karonga and Niamey regarding recent donor funded interventions. Similarly, Revi et al. [12] (p. 27) also caution that care is required from governments and potential funders in supporting alternative forms of risk reduction led by citizen movements as "this very support can co-opt and 
destroy the alternative ethos, governance form and pro-poor adaptation movement" that is important for transformative development.

The examples presented in this paper also illustrate the considerable potential for researchers to work in partnership with practitioners and stakeholders to support a transition towards a more integrated vision, process and practice of risk management. For example, Urban ARK researchers supported the formation of the Nairobi Urban Risk Partnership, the formation of DRM committees in Mzuzu, and the establishment of a city stakeholder's platform on risk reduction in Ibadan, with the aim of developing an action plan for risk reduction in the city. Collaborating with the multiplicity of urban actors including city officials, civil society, community members at risk and other key stakeholders from the outset has been central to these initiatives. Trust building and on-going communication across formal and informal channels are essential and science can play a role in providing additional data or information to further strengthen the community voice and advocacy positions. Furthermore, gaps in data and monitoring capacities require urgent attention and there is considerable potential for community collected and owned data to help address this gap, particularly around extensive risk data [37]. Robust data is critical for supporting evidence-based decision making but also, use of common methodologies for data collection can bring diverse state and non-state stakeholders together around a specific task. This can help build collective ownership and action across a range of issues and contexts.

It is well recognised that the diversity of urban sSA contexts calls for flexible and context-specific approaches to risk management [38]. However, through the lens of the transitions framework presented, the paper has demonstrated several key mechanisms, blockages and opportunities for acting on the processes that can enable a transition towards more risk-sensitive and transformative urban development across diverse urban contexts. As illustrated in Figure 1, achieving the SDGs will require a transition in the risk-development nexus where risk management is mainstreamed with development, and development is seen as a root cause of risk and as a focus for change. It also requires that we focus squarely on the processes and procedures that can enable a transition towards more risk-sensitive and transformative urban development across all scales and contexts. Moving forward to achieve this will require more inclusive governance, strengthened networked collaboration and collective action, locally accountable leadership and improved risk data and monitoring.

Author Contributions: All authors contributed to Conceptualization, Methodology, Formal Analysis, Investigation, Data Curation, Writing-Original Draft Preparation, Writing, Review \& Editing.

Funding: This research and paper was supported by the Urban Africa: Risk Knowledge (Urban ARK) programme, funded by the UK Economic and Social Research Council (ESRC) and Department for International Development Humanitarian Innovation and Evidence Programme under Grant No. ES/L008777/1.

Conflicts of Interest: The authors declare no conflicts of interest.

\section{References}

1. Jones, R.N.; Preston, B.L. Adaptation and risk management. Wiley Interdiscip. Rev. Clim. Chang. 2011, 2, 296-308. [CrossRef]

2. Fraser, A.; Leck, H.; Pelling, M.; Parnell, S. Africa's Urban Risk and Resilience, Editorial. Int. J. Disaster Risk Reduct. 2017, 26, 1-6. [CrossRef]

3. Satterthwaite, D. The impact of urban development on risk in sub-Saharan Africa's cities with a focus on small and intermediate urban centres. Int. J. Disaster Risk Reduct. 2017, 26, 16-23. [CrossRef]

4. Dodman, D.; Leck, H.; Rusca, M.; Colenbrander, S. African urbanisation and urbanism: Implications for risk accumulation and reduction. Int. J. Disaster Risk Reduct. 2017. [CrossRef]

5. Pelling, M.; Leck, H.; Pasquini, L.; Ajibade, I.; Osuteye, E.; Parnell, S.; Lwasa, S.; Johnson, C.; Fraser, A.; Barcena, A.; et al. Africa's urban adaptation transition under a $1.5^{\circ}$ climate. Curr. Opin. Environ. Sustain. 2017, 31, 10-15. [CrossRef]

6. Thomalla, F.; Boyland, M.; Johnson, K.; Ensor, J.; Tuhkanen, H.; Gerger Swartling, Å.; Han, G.; Forrester, J.; Wahl, D. Transforming Development and Disaster Risk. Sustainability 2018, 10, 1458. [CrossRef] 
7. Brown, D.; Leck, H.; Johnson, C.; Pelling, M. Urban Africa: Risk Knowledge-A Research Agenda . Urban Africa Risk Knowledge Briefing No. January 2017. Available online: https://www.urbanark.org/sites / default/files/resources/UrbanArk_briefing_1_Urban\%20ARK\%20intro_FINAL\%20web\%5B2\%5D.pdf (accessed on 20 July 2018).

8. Manda, M. Where there is no local government: Addressing disaster risk reduction in a small town in Malawi. Environ. Urban. 2014, 26, 586-599. [CrossRef]

9. Edwards, G.A.S.; Bulkeley, H. Heterotopia and the urban politics of climate change experimentation. Environ. Plan. D Soc. Space 2017, 36, 350-369. [CrossRef]

10. Roberts, D.; O'Donoghue, S. Urban environmental challenges and climate change action in Durban, South Africa. Environ. Urban. 2013, 25, 299-319. [CrossRef]

11. Pelling, M.; O’Brien, K.; Matyas, D. Adaptation and transformation. Clim. Chang. 2015, 133, $113-127$. [CrossRef]

12. Revi, R.; Satterthwaite, D.; Aragón-Durand, F.; Corfee-Morlot, J.; Kiunsi, R.; Pelling, M.; Roberts, D.; Solecki, W.; Pahwa Gajjar, S.; Sverdlik, A. Towards transformative adaptation in cities: The IPCC's Fifth Assessment. Environ. Urban. 2014, 26, 11-28. [CrossRef]

13. Adelekan, I.; Johnson, C.; Manda, M.; Matyas, D.; Mberu, B.; Parnell, S.; Pelling, M.; Satterthwaite, D.; Vivekananda, J. Disaster risk and its reduction: An agenda for urban Africa. Int. Dev. Plan. Rev. 2015, 37, 33-43. [CrossRef]

14. Ajibade, J.; Agboola, J.; Pelling, M. Sustainability transitions: Exploring risk management and the future of adaptation in Lagos. J. Extreme Events 2017, 3, 1-25. [CrossRef]

15. Kemp, R.; Loorbach, D.; Rotmans, J. Transition management as a model for managing processes of co-evolution towards sustainable development. Int. J. Sustain. Dev. World Ecol. 2007, 14, 78-91. [CrossRef]

16. Pelling, M. Adaptation to Climate Change: From Resilience to Transformation; Routledge: London, UK, 2010.

17. Makau, J.; Dobson, S.; Samia, E. The five-city enumeration: The role of participatory enumerations in developing community capacity and partnerships with government in Uganda. Environ. Urban. 2012, 24, 31-46. [CrossRef]

18. Solecki, W.; Pelling, M.; Garschagen, M. Transitions between risk management regimes in megacities. Ecol. Soc. 2017, 22, 38. [CrossRef]

19. Conway, D.; Schipper, L. Adaptation to climate change in Africa: Challenges and opportunities identified from Ethiopia. Glob. Environ. Chang. 2011, 21, 227-237. [CrossRef]

20. Ziervogel, G.; Pelling, M.; Cartwright, A.; Chu, E.; Deshpande, T.; Harris, L.; Hyams, K.; Kaunda, J.; Klaus, B.; Michael, K.; et al. Inserting rights and justice into urban resilience: A focus on everyday risk. Environ. Urban. 2017, 29, 123-138. [CrossRef]

21. Dodman, D.; Leck, H.; Pelling, M.; Adelekan, I.; Brown, D.; Manda, M.; Mberu, B.; Maria Rusca, M.; Satterthwaite, D.; Taylor, F. A Spectrum of Methods for a Spectrum of Risk: Generating evidence to understand and reduce urban risk in SubSaharan Africa. 2018. under review.

22. Wanda, E.; Manda, M.; Msiska, O.; Kamlomo, D.; Kushe, J.; Mphande, C.; Kaunda, J. Analysis of governance of water, sanitation and hygiene (WASH) in Karonga Town, Malawi. Int. J. Disaster Risk Reduct. 2017, 26, 69-77. [CrossRef]

23. Holm, R.; Kamangira, A.; Tembo, M.; Kasulo, V.; Kandaya, H.; Van Enk, P.G.; Velzeboer, A. Sanitation service delivery in smaller urban areas (Mzuzu and Karonga, Malawi). Environ. Urban. 2018, 1-16. [CrossRef]

24. Manda, M.; Wanda, E. Understanding the nature and scale of risks in Karonga, Malawi. Environ. Urban. 2017, 29, 15-32. [CrossRef]

25. Runduka, R.M.; Phiri, R.; Kambani, C.; Boyer, C. Malawi Disaster Risk Reduction and Climate Adaptation; Research for Cordaid: Lilongwe, Malawi, 2010.

26. World Bank. Malawi Floods Emergency Recovery. 2015. Available online: http://projects.worldbank.org/ P154803/?lang=en\&tab=overview (accessed on 20 July 2018).

27. Adelekan, I. Urban dynamics and vulnerability to everyday hazards and disasters in Ibadan, Nigeria. Environ. Urban. 2018. under review.

28. Olaniyan, F.; Adelekan, I.; Nwokocha, E. The Role of Local Governments in Reducing Disaster Losses and Vulnerabilities in Ibadan. Working Paper 2018; Urban Africa: Risk Knowledge Programme. 2018. Available online: https: / /www.urbanark.org (accessed on 20 July 2018).

29. Myers, G. Urban. Environments in Africa: A Critical Analysis of Environmental Politics; Policy Press: Bristol, UK, 2016. 
30. African Population and Health Research Center (APHRC). Solid Waste Management and Risks to Health in Urban. Africa-A Study of Nairobi and Mombasa Cities in Kenya; African Population and Health Research Center: Nairobi, Kenya, 2017.

31. Kimani, N.G. Environmental Pollution and Impact to Public Health: Implications of the Dandora Municipal Dumping Site in Nairobi; UNEP: Nairobi, Kenya, 2007.

32. Onyango, P. Devolution Made Simple: A Popular Version of County Governance System. 2013. Available online: http:/ / library.fes.de/pdf-files/bueros/kenia/09856.pdf (accessed on 20 July 2018).

33. Mitra, S.; Mulligan, J.; Schilling, P.; Harper, J.; Vivekananda, J.; Krause, L. Developing risk or resilience? Effects of slum upgrading on the social contract and social cohesion in Kibera, Nairobi. Environ. Urban. 2017, 29, 103-122. [CrossRef]

34. Ngobi, B.; Mulligan, J. The Institutional and Regulatory Context for Flood Risk Reduction in Nairobi. Final Briefing Paper, 2015-2016, Kounkuey Design Initiative. 2018. Available online: https:/ /www.dropbox.com/s / v9o5lga2cfkuxjn/170405\%20Final\%20Institutional\%20Mapping\%20Report_KDI_Screenview.pdf?dl=0 (accessed on 1 March 2018).

35. Satterthwaite, D.; Bartlett, S. Editorial: The full spectrum of risk in urban centres: Changing perceptions, changing priorities. Environ. Urban. 2017, 29, 3-14. [CrossRef]

36. Allen, A.; Koroma, B.; Osuteye, E.; Rigon, A. Urban Risk in Freetown's Informal Settlements: Making the Invisible Visible. Urban Africa Risk Knowledge Briefing No. 2017. Available online: https:/ /www.urbanark. org/sites/default/files/resources/UrbanArk_briefing_6_web\%5B1\%5D.pdf (accessed on 6 April 2017).

37. Satterthwaite, D. Health in Urban Slums depends on better local data. Presented at the International Conference on Urban Health, Manchester, UK, 5-7 March 2014.

38. Issaka, H. Exode rural, urbanisation et sécurité privée à Niamey. Les Cahiers d'Outre-Mer 2018, 270, $225-242$. [CrossRef]

39. Boubacar, S.; Pelling, M.; Barcena, A.; Montandon, R. The erosive effects of small disasters on household absorptive capacity in Niamey: A nested HEA approach. Environ. Urban. 2017, 29, 33-50. [CrossRef]

40. Issoufou, O.H.; Lecumberri, N.; Boubacar, S. Urban Profile: Flood Risk Areas and other Risks in the City of Niamey (Niger). Urban Africa Risk Knowledge, Working Paper No. 2015. Available online: www.urbanark. org/urban-profile-flood-risk-areas-and-other-risks-city-niamey-niger (accessed on 20 July 2018).

41. Niang, I.; Ruppel, O.C.; Abdrabo, M.A.; Essel, A.; Lennard, C.; Padgham, J.; Urquhart, P.; Adelekan, I.; Archibald, S.; Balinga, M.; et al. Africa. In Climate Change 2014: Impacts, Adaptation, and Vulnerability, Part B: Regional Aspects; Contribution of Working Group II to the Fifth Assessment Report of the Intergovernmental Panel on Climate Change; Cambridge University Press: Cambridge, UK; New York, NY, USA, 2014; pp. 1199-1265. Available online: http:/ / www.ipcc.ch/pdf/assessment-report/ar5/wg2/WGIIAR5-Chap22_ FINAL.pdf (accessed on 1 March 2018).

42. PGRC-DU. Niger Disaster Risk Management and Urban Development Project. World Bank. 2018. Available online: http:/ / documents.worldbank.org/curated/en/364941523301552125/pdf/Disclosable-Version-ofthe-ISR-Niger-Disaster-Risk-Management-and-Urban-Development-Project-P145268-Sequence-No-08. pdf (accessed on 20 July 2018).

43. Casse, C.; Gosset, M. Analysis of hydrological changes and flood increase in Niamey based on the PERSIANN-CDR satellite rainfall estimate and hydrological simulations over the 1983-2013 period. IAHS-AISH Proc. Rep. 2015, 370, 117-123. [CrossRef]

44. Sudmeier-Rieux, K.; Jaboyedoff, M.; Fra.Paleo, U.; Garschagen, M.; Renaud, F.G.; Estrella, M. Opportunities, incentives and challenges to risk sensitive land use planning: Lessons from Nepal, Spain and Vietnam. Int. J. Disaster Risk Reduct. 2015, 14, 205-224. [CrossRef]

45. Pelling, M.; Wisner, B. (Eds.) Disaster Risk Reduction: Cases from Urban. Africa; Earthscan: London, UK, 2009; p. 224.

46. Satterthwaite, D.; Sverdlik, A.; Brown, D. Revealing and Responding to Multiple Health Risks in Informal Settlements in sub-Saharan Africa. Available online: https:/ link.springer.com/article/10.1007/s11524-0180264-4 (accessed on 20 July 2018).

47. Castán Broto, V. Viewpoint: Planning for climate change in the African city. IDPR 2014, 36, 257-264.

48. Allen, A.; Walnycki, A.; von Bertrab, É. The co-production of water justice in Latin American cities. In Just Urban Futures: Environmental Justice and Resilience in the Urban Global South; Palgrave McMillan: London, UK, 2015. 
49. Mitlin, D. With and beyond the state-Co-production as a route to political influence, power and transformation for grassroots organizations. Environ. Urban. 2008, 20, 339-360. [CrossRef]

(C) 2018 by the authors. Licensee MDPI, Basel, Switzerland. This article is an open access article distributed under the terms and conditions of the Creative Commons Attribution (CC BY) license (http://creativecommons.org/licenses/by/4.0/). 